\title{
LICE I NALIČJE JEDNOG VLADARA: PORTRET MATIJE KORVINA U ISTORIOGRAFSKOM SPISU ITALIJANSKOG HUMANISTE*
}

U radu se posmatra lik i delo ugarskog kralja Matije Korvina iz vizure italijanskog humanista rodom iz Askolija, Antonija Bonfinija. Prvih osam knjiga dela Rerum Ungaricarum Decades, tomus $I V$, učeni pisac posvetio je vladaru Ugarske. Hronološki, rad obuhvata period od Matijinog svečanog krunisanja krunom "sv. Stefana" 1464. do njegove smrti 1490. godine. Kazivanje italijanskog humaniste poredi se sa drugim raspoloživim izvorima. Mnogi istraživači iznose konstataciju o Bonfinijevoj pristrasnosti kada piše o Matiji. Međutim, pažljim iščitavanjem dela lako se uočava da on podjenako iznosi mnogobrojne vrline, ali i mane ugarskog vladara. Kralj Matija bio je izuzetno hrabar vojnik koji se nije štedeo u ratnim pohodima. Bonfini navodi brojne primere njegove ratničke neustrašivosti, što potvrđuju i drugi izvori. Ugarski kralj je, prema kazivanju Bonfinija, bio po prirodi slobodouman i velikodušan, željan slave i poštovanja. Svestrano obrazovan, snažno je podržavao razvoj humanizma i renesanse u Ugarskoj. Iako pobožan, pre svake vojne kampanje obavezno je konsultovao astrologe. Vojskovođe i prijatelje bogato je darivao. Međutim, sa neprijateljima se surovo obračunavao.

Ključne reči: Antonio Bonfini, kralj Matija Korvin.

Matija Korvin (1458-1490) bio je jedan od najvećih vladara srednjovekovne Ugarske. Svojim vojnim podvizima i drugim delima snažno je obeležio istoriju druge polovine XV veka. Dugo je, kao neumorni zaštitnik kulture i umetnosti, tragao za ličnošću dostojnom da ovekoveči istoriju Ugarske. Zadatak je na koncu poverio vrsnom filologu i humanisti rodom iz mesta Patrinjone u Askoliju, Antoniju Bonfiniju (1427-1502). Ovaj je napisao delo Rerum Ungaricarum decases, u 45 knjiga, podeljeno na pet dekada. U prvih osam knjiga četvrte dekade narečenog dela autor piše o političkim, društvenim, verskim i kuturnim prilikama u Ugarskoj i okolnim zemljama od 1464. do 1490. godine. Na mnogim mestima, direktno ili indirekto autor nam pripoveda o ličnosti kralja Matije, njegovim vrlinama i manama.

Ugarski kralj gotovo ceo život proveo je na ratištima diljem Evrope i sve do smrti "više zadovoljstva pronalazio je u oružju nego u spokoju" (Bonfinis, 1976, 40). Nikada nije imao mira, neprestano stremeći slavi i besmrtnosti. Odlično je podnosio napor i nespavanje, nepogrešivo znao da proceni kada prema vojsci treba

* sbozanic5@gmail.com-necmoli@orion.rs 
biti strog, a kada blag. Dezertere i izdajnike uvek je neumoljivo kažnjavao. Ako je verovati Bonfiniju, na brzim kolima znao je svakodnevno da prevali i po $62 \mathrm{~km}$.

Kralj Matija je bio izuzetno hrabar vojnik koji se nije štedeo u brojnim ratnim pohodima. Bonfini navodi silne primere njegove ratničke neustrašivosti, a njegove tvrdnje potkrepljuju i drugi izvori.

U trećoj knjizi donosi interesantnu epizodu o Matijinom podvigu prilikom osvajanja Šapca. Kako bi dodatno ispitao "fortifikaciju i odbranu" utvrđenja, kralj se prerušio u običnog vojnika i u pratnji ličnog sluge i veslača, u malenom čunu, oplovio čitavo utvrđenje. Doznavši za to, Turci su topom pokosili njegovog pratioca. No, Matija se nije dao omesti. On je "neustrašivo nastavio plovidbu i to se s pravom smatralo izuzetno odvažnim podvigom", piše Bonfini u šestoj knjizi. Njegovo pisanje potvrđuje Gabrijel iz Verone, koji je o pomenutom događaju u pismu obavestio papu Siksta IV (Thallóczy \& Áldásy, 1907, 389-390). I sam Matija, u jednom sačuvanom dokumentu, potvrđuje da je u osvajanje Šapca uložio mnogo napora, truda, troškova i ljudi (Fraknói, 1896, 259-261). Ugarsko osvajanje Šapca od Turaka, 15. februara 1476. izazvalo je veliko oduševljenje u Rimu, Veneciji i celom hrišćanskom svetu.

Nalazeći se u velikim materijalnim problemima, Matija je 1467. izvršio reformu poreskog sistema. Uveo je tributum fisci regalis i vectigal sacrae coronae, pri čemu Bonfini ove podatke ne navodi eksplicitno (Klaić, 1973, 90). Fiskalne novine izazvale su opšte nezadovoljstvo plemstva i seljaka. Najpre je izbio ustanak u Transilvaniji, a potom i u Moldaviji (Kisić, 2012, 129-131). Ratne operacije odvijale su se tokom novembra i decembra narečene godine. Najžešći sukob odigrao se 15. decembra 1467. godine kod grada Banje (Baia). Vladar se te noći nalazio na samom čelu najžešćih okršaja, "čas bodreći hrabre, čas podižući moral plašljivijima, čas dolazeći u pomoć onima na najkritičnijim pozicijama" (Kisić, 2012, 133134). Pomenute noći, Matija se nije štedeo - istovremeno je branio rezidenciju sa veteranima i pritrčavao u pomoć odredima na trgu. Koliko je tokom boja vladar bio izložen opasnosti najbolje svedoči činjenica da ga je "getska strela" pogodila u leđa, nedaleko od kičme. Sa bojnog poprišta odnet je na nosiljci (Klaić, 1973, 92). Naredne četiri godine zbog toga je imao ozbiljnih zdravstvenih problema, "zalečivanje rane izazvalo je urastanje metala, sve dok ga organizam sam nije izbacio kao strano telo" (Bonfinis, 1976, 17).

Za ugarskog kralja jeritička pošast nije bila ništa manje opasna od Turaka (Bonfinis 1976, 21). Pošto se češka jeres nadvila nad granicama Ugarske, Matija je ušao u rat za spas duša a ne za puki fizički opstanak. Stoga se nije libio da se suprotstavi soptvenom tastu, Đorđu Pođebradu (1458-1471). Bez obzira što je rana zadobijena u Moldaviji još uvek bila sveža, odbrana domovine vraćala mu je snagu i entuzijazam (Bonfinis, 1976, 23). Ratne operacije uveliko su trajale, kada je Matija primio vest da je 22. marta 1471. godine umro njegovo tast (Fraknói 1896: 240). Italijanski pisac nije siguran da li je Matija istinski tugovao za Pođebradom ili je "vešto odglumio žalost" (Bonfinis, 1976, 33).

Kralj nije odustajao od borbe ni kada bi situacija delovala posve beznadežno. U izuzetno nepovoljnom položaju našao se 1473, kada je istovremeno buknuo rat 
i sa Češkom i sa Poljskom, dok na sve ni turski nije jenjavao. Vojska poljskog kralja Kazimira IV Jagelonca (1447-1492) i njegovog sina Vladislava brojala je oko 60000 vojnika, a ugarski vladar jedva je sakupio između 8 i 10000 vojnika. Međutim, ni tada nije klonuo duhom. Njegova ratna taktika pod Vroclavom pokazala se veoma uspešnom. Uz minimalne gubitke i svakodnevne sitne čarke, nije prošao dan a da ne zarobi 20 ili 30 neprijatelja. Neprekidno je protivniku nanosio ozbiljnu štetu. Poslao je najodanije vojskovođe da poharaju, spale i opustoše što veći deo poljske teritorije. Situacija je bila toliko teška da je poljska kraljica Elizabeta molila supruga i sina da se što pre vrate i brane kraljevstvo. Grof Đorđe Branković u Hronikama piše da su knez Pavle Branković i grof Stefan Sepeški krenuli na "Lešku zemlju" (Poljska) i stigli su do Krakova. Na to je "leška kraljica" poslala poruku suprugu i sinu (Radonić, 1911, 812-814).

Kao izuzetan vojskovođa i vojni strateg, Matija je prilikom ratnih operacija znao da sasluša i uvaži predloge najbližih saradnika. Za vreme opsade Vroclava prihvatio je savet mladog pisara Tome da treba postaviti logore i izvan grada, $i$ unutar njega. Opisujući opsadu Hajnburga, Bonfini jedino pominje despota Vuka koji je mudro savatovao vladara da nije pametno zapodenuti otvorenu bitku "zbog brojne nadmoći i ozbiljne vojne opreme protivnika". Nakon bezuspešne dvomesečne opsade Zvornika, Emerih Zapolja vršio je stalni pritisak na Matiju da povuče logor i da se trupe vrate kući sa ranije zadobijenom pobedom i raskošnim plenom. Na kraju, Matija je obustavio opsadu. Bonfini konstatuje da se ugarska vojska "zahvaljujući Emeriku sramno dala u beg pred Zvornikom" (Bonfinis, 1976, 3).

Njegova vojska neretko je znala da bude veoma surova i opasna. Opisujući rat vođen između Matije i Fridriha III Habzburškog (1440-1493), Bonfini nabraja zverstva ugarske vojske u kojoj je bilo i srpskih četa. Tim događajima posvetio je najveći deo pete knjige. U Matijinoj objavi rata Fridrihu III koju pisac donosi u celini, vladar Ugarske navodi da se rimsko-nemački car oglušio o savezništvo te da je njegova vojska dušmanski napadala i pljačkala ugarsku teritoriju, sela i gradove. Stoga mu je objavio "pravičan rat". Kraljevu vojsku od oko 10000 ratnika činili su Česi, Ugari i Srbi. U njegovoj pratnji našli su se Stefan Sepeški, Pavle Kinjiži, Nikola Banfi, braća Jakšić, Petar i Emerik Doci na čelu barjaktara, despot Vuk Grgurević, Bertold Elderbah, vojvoda Lavrencije i drugi plemići. Iz teksta se doznaje da je Matiju pratila supruga, ali nigde se ne pominje da je poveo i majku Elizabetu. Trebalo je da njih dve zajedno vide njegovu slavu (Klaić, 1973, 129). Najpre su pali Trauterstrof (Trautmansdorf) i Peterstrof (Petersdorf), mesta u neposrednoj blizini Beča. Pisac ističe surovost srpskih četa lišenih svake samilosti. Poput Turaka sve su putošile "ognjem i mačem". Mnoge crkve su tom prilikom poharane. Razarali su "božansko i ljudsko bez ikakve razlike". Izazivali su toliki strah kod lokalnog stanovništva da su i "okolni gradovi ponudili predaju". Stanovnici Beča bili su prestrašeni. Matijina vojska "slobodno je tumarala po čitavoj regiji vršeći pokolje". U toku jednog dana, iz silnog straha, Matiji se predalo 14 naselja koja su "poput venca" okruživala prestonicu. Brzo su pali Baden, Peterstrof, Trauter- 
strof, Lihtenštajn, Medling, Sv. Margarita, Švandorf, Klosternojburg i drugi kašteli. Ugarska vojska bila je jednako surova i prilikom osvajanja Kremsa i Stajna. Pustošili su i pljačkali sela, sejući strah i užas. Lokalno stanovništvo zarobljavano je ili ubijano ukoliko bi se usprotivilo ugarskoj vojsci. Kolika je bila svirepost ugarskih trupa najbolje se vidi iz obraćanja Fridrihove delegacije Matiji. Smatrali su da ugarski kralj sa njima postupa kao sa Turcima, premda oni "niti su Turci, niti neljudi, niti zveri". Ugarskim vojnicima nije bilo strano ni pljačkanje crkava, silovanje devojaka i pokolj. Ako je verovati Bonfiniju, Beatriče je svakodnevno u pismima molila Matiju da savlada bes i usmeri se "na sklapanje mira i opštu dobrobitit". Primirje, a potom i mir dogovoreni su 10. novembra 1477. godine. Fridrih III 1. decembra potvrdio je mir u Gmundenu, a kralj Matija 17 dana kasnije u Kornojburgu. Osnovnu karakteristiku ovog rata predstavlja veliko zverstvo ugarskih trupa. Ne samo srpski odredi, već celokupna Matijina vojska koja je dugo ratovala sa Osmanlijama, te je preuzela od njih dobrim delom način ratovananja i vojnu taktiku. O stradanju gradova u Austriji, krajem XIX veka, pisao je V. Fraknói (Fraknói 1896: 265). Dušanka Dinić Knežević iz perspektive srpske istoriografije, ponovila je konstataciju o nehumanosti srpske vojske (Dinić-Knežević, 1975, 41).

Odane saradnike i hrabre vojnike kralj je poštovao i vazda bogato nagrađivao. Jedan od njegovih najvećih prijatelja bio je Ivan Vitez od Sredne (1405-1472), najistaknutiji predstavnik humanizma i renesanse XV veka na prostoru jugoistočne Evrope (Božanić \& Kisić, 2013, 160). Prilikom krunisanja 1464. godine, Vitezu i njegovim potomcima svečano je obećao bogatu Bihorsku županiju "da njegova vrlina ne prođe bez nagrade i zahvalnosti koje zavređuje" (Bonfinis 1976: 1). On mu je bio uzdanica "kako savetom, tako i podvigom, i u otadžbini, i van nje" (Bonfinis 1976: 1). U svečanom govoru nakon krunisanja, istakako je Vitezovu posredničku ulogu u delikatnim pregovorima sa Fridrihom III oko vraćanja krune sv. Stefana u Budim. Kao blizak saradnik i vaspitač, učestvovao je u oslobađanju kralja Matije Korvina iz praške tamnice. On je bio saborac koji nikad nije napustio Matijin vojni logor. Pratio ga je prilikom ratnih pohoda po Češkoj, Turskoj, Transilvaniji i Bosni. Zajedno su delili dobro i zlo.

Za saborce je, prema Bonfiniju, imao sjajne i neverovatne junake. Prilikom rata sa Pođebradom, u njegovoj pratnji bili su Nikola Čupor, erdeljski vojvoda, Stefan Batori, palatin Mihailo, kapetan Blaž, Pavle Kinjiži, despot Vuk, Nikola Banfi, obojica nadbiskupa, Ivan Česmički i niz drugih uglednih plemića. Pomenute ličnosti Bonfini poredi sa junacima iz Trojanskog rata: Odisejem, Palamedom, Ajantom, Diomedom, Nestorom, dok za samog Matiju beleži da je "bio slika i prilika Ahilova" (Bonfinis, 1976, 27). Nakon završetka rata, nemali broj saradnika po zasluzi je darivao i uzvisio. Italijanski pisac posebno ističe, da je zbog izuzetne hrabrosti i požrtvovanosti posebno "obasuo počastima" Stefana Batorija i despota Vuka. Srpski despot je bio "skromnog posedničkog statusa", te mu je dodelio "castellum Feyczkeo". Reč je o Beloj Steni u Križevačkoj županiji (Ruvarac, 1934, 299-302; Dinić-Knežević, 1975, 8). 
U ratu protiv Poljaka (1473-1474), prema Bonfiniju naročito su se istakli despot Vuk Grgurević, predvodnik barjaktara Dmitar Jakšić, Pavle Kinjiži i Srefan Batori. Svi su bili bogato nagrađeni. Batori je tom prilikom dobio grad Trenčin sa pripadajućim selima i posedima. Nije moguće na osnovu Bonfinija tvrditi da li je despot Vuk 1474. dobio Berkasovo jer pisac eksplicitno ne spominje ime mesta, već samo da je za zasluge darivan (Dinić-Knežević, 1975, 23-24).

Za srpsku istoriografiju, Bonfini donosi značajne podatke o odnosu između kralja Matije i despota Srba u južnoj Ugarskoj (Ćirković, 1970, 286-287). Da Vuk Grgurević "uživa veliki ugled kod Matije" znao je i turski sultan Mehmed II Osvajač (Bonfinis, 1976, 9). On je pokušao preko njega da osujeti savez između Ugarske i Venecije. To potvrđuje i čuveno pismo kralja Matije mletačkom duždu Hristiforu Mauru od 18. februara 1465. godine (Fraknói, 1893, 78). Prema italijanskom humanisti, despot Vuk je jedan od "kraljevih najbližih saradnika", hrabar, požrtvovan i prekaljeni ratnik. Srpski despot je "ličnost izuzetne neukrotive snage i postojanosti".

Iz III knjige doznaje se da je velikaš Dmitar Jakšić odigrao izuzetno značajnu ulogu prilikom osvajanja 1474. godine Nađmihalja i Humenje (Homona). Kako bi se obračunao sa poljskim vojnicima, pored vojvode Čupora, pozvao je Dmitra Jakšića "zapovednika barjaktara i lake konjice". On je pokazao izuzetnu hrabrost i bio jedan od najzaslužnijih vojnika što su pomenuta utvrđenja pala (Ivić, 1929, 18-19; Radonić, 1923, 61-76).

Čak i onda kada je fizički bio sprečen, zaokupljen ratovanjem na drugim stranama, njegovi odani velikaši su se hrabro borili za čast i slavu Ugarske. Stefan Batori, Pavle Kinjiži i Dmitar Jakšić, uspešno su se suprotstavili Turcima na Hlebnom polju (Kenyérmezö) 13. oktobra 1479. godine, na dan Svetog Kolomana (Ivić, 1909, 26; Jorga, 1934, 115; Babinger 1968, 326; Rokai i dr., 2002, 166).

U leto 1476. Matijine trupe odnele su sjajnu pobedu nad Turcima, kod Požežene. Na vest da je Ali-beg uz pratnju 4000 najokretnijih konjanika prešao Dunav, Matija je poslao u dotičnu oblast despota Vuka Grgureviča, branitelje Temišvara, Alberta i Ambrozija Nađa, Dmitra Jakšiča i trojicu zapovednika barjaktara iz familije Doci - Petra, Emerika i Ladislava. Bonfini ističe hrabrost zapovednika Beograda, Imre Nifora i Kepli Janoša, koji su predvodili odrede konjice (Kalić-Mijušković, 1967, 196, 197). Pred Matiju je posle bitke dovedeno 250 zarobljenika, uz zaplenjenih pet neprijateljskih barjaka i bogat plen (Dinić-Knežević, 1975, 12). Pobeda nad Osmanlijama podjednako je obradovala sve hrišćanske vladare.

Dok je Matija bio zaokupljen opsadom Hajnburga, Pavle Kinjiži, despot Vuk, Petar Doci i drugi plemići sukobili su se 9. septembra 1482. godine, kod Bečeja, sa Turcima (Ivić, 1909, 29). Nakon bitke, Pavle Kinjiži je veliki deo zadobijenog plena poslao kralju Matiji kao svedočanstvo o zadobijenoj pobedi. Pored Bonfinija, o ovoj pobedi ugarske vojske svedoče i drugi izvori.

Italijanski humanista se u VI knjizi kratko osvrće na bitku kod Une. Hrvatski ban Matija Gereb, despot Vuk Grgurević, Bernardin Frankopan i drugi istaknuti velikaši na Uni sačekali su Turke, koji su prethodno pustošili područje Hrvatske, Koruške i Kranjske (Klaić, 1973, 164-167). Bitka je trajala dva dana, 29-30. oktobar 
i završila se potpunim slomom protivnika. Pomenuta bitka predstavlja poslednje aktivno vojno angažovanje despota Vuka Grgurevića (Dinić-Knežević, 1975, 17).

Dok je prema prijateljima bio sušta dobrota i obasipao ih dobročinstvima, neprijateljima se gorko svetio i svirepo ih kažnjavao, kazuje Bonfini (Bonfinis, 1976, 167).

Kralj Matija se surovo obračunao 1465. godine sa češkim najamnicima i njihovim vođom (Rokai, Đere, Pal, \& Kasaš, 2002, 162). Oni su na prostoru severne Ugarske načinili brojne zločine nad lokalnim stanovništvom. Spaljivali su sela uz bezobzirnu pljačku, otimali su stoku i odvodili narod u zarobljeništvo. Švehla, njihov vođa, zauzeo je tvrđavu Kostolanj koja se nalazila na severozapadu Ugarske (Slovačka). Pošto je na kraju vođa najamnika zarobljen, kralj Matija održao je poduži govor koji je završio rečima: "Umri i time kruniši lanac nedela!" (Bonfinis, 1976, 7). Uskoro je razapet na krstu pred kapijom tvrđave Kostolanj. Bonfini dodaje da od ukupno 7000 ljudi koji su pripadali Českom bratstvu niko nije ostao živ. Svi do jednog su stradali, što od mača, što od gladi.

Ništa bolje nisu prošli ni vođe pobune u Transilvaniji 1467. godine. Najpre je na saboru u Tordi pomilovao Jovana i sudije, dok je Benedikta Rufa (Benedikt Farnaši Vereš), glavnog kolovođu ustanka, preselio u Poljsku. Pošto je uskoro u Sibinju čuo da su se neki prestupnici oglušili o presudu, izdao je naredbu da se buntovnici i izdajnici uhapse i kazne smrću. Na glavnom trgu, osmorica prestupnika je pogubljena, a među njima su se nalazili gradski pretor Jovan Heri, Mihailo Suka i Petar Gereb.

Međutim, Matija je znao i da oprašta neposlušnost prijatelja. Naime, tokom pohoda na Transilvaniju od njega se odmetnuo vojskovođa Emerik koji je napustio vojni logor. On je bio jedan od najbližih saradnika kraljevog oca. Iako su bili osvedočeni prijatelji, Emerika je iziritirala preterana kraljeva samovolja i insistiranje na slepoj pokornosti. Nadasve, mudri Matija je znao da ne sme izgubiti tako uglednog, uzornog i mudrog čoveka. Stoga je poslao ostrogonskog nadbiskupa da reši problem. Na povratku iz Moldavije, Emerik ga je dočekao sa svojim trupama i zakleo se na vernost. Ponovo su uspostavljeni pređašnji dobri odnosi (Bonfinis, 1976, 15).

Prema Bonfiniju, ugarski kralj je uživao je u ratovanju, dok su ga dokolica i nerad ubijali. Retke trenutke između vojnih pohoda i državnih poslova, koristio je za organizovanje najrazličitijih društvenih događaja u kojima je lično uzimao učešća. Od rane mladosti uživao je u viteškim turnirima i takmičenju dvokolicama. Često je u Beču i Budimu lično učestvovao na turnirima. Primera radi, leto posle krunisanja 1464. godine proveo je u Budimu. Tom prilikom državani su viteški turniri, lov na lavove i "dva ili tri gladijatorska nadmetanja na dan (a njih je posebno voleo) i slično" (Bonfinis, 1976, 2). Italijanski humanista piše da se kralj nikada nije prepuštao lenjosti i dokolici. Ugarski vladar ravnopravno se nadmetao na viteškim turnirima, pri čemu bi posebno zapovedio da se na turnirima ni najmanje ne uzimaju u obzir ni njegovo dostojanstvo ni titula. Takve poteze "često je potvrđivao i zvaničnim ediktima" (Bonfinis, 1976, 2). Neretko je lično upravljao 
trkačkim dvokolicama. Sve što je činio, voleo je da bude otvoreno i pred očima javnosti.

Matija je prema kazivanju Bonfinija, bio po prirodi slobodouman i velikodušan, željan slave i poštovanja. Uvek je bio spreman na na velike i rizične podvige. Voleo je ratnički poziv i bez problema podnosio napor i glad. Nastojao je da svojom slavom nadmaši antičke uzore vojskovođa. Krasio ga je slobodan, otvoren i borben duh, te je sa njim bilo lako zaratiti i sklopiti mir.

Opisujući rat protiv češkog kralja Đorđa Pođebrada, italijanski pisac ističe "urođenu slavoljubivost" ugarskog kralja (Božanić, 2012, 415-425). Na pohod protiv jeretičkog kralja su ga vodili ljubav i obziri verske prirode, te podrška pape i Fridriha III, ali i i činjenica da je ,zarad težnje besmrtnosti bio kadar da prezre i najveću opasnost" (Bonfinis, 1976, 19). Isto tako, prilikom već pomenutih ratnih događaja u Baji 1467. vladar se "nije borio za čast, slavu ili dostojanstvo, već za goli opstanak", konstatuje Bonfini.

Jednog od najvećih srednjovekovnih vladara Ugarske krasile je visoka inteligencija. Po pamćenju nije zaostajao za Scipionom, Mitridatom ili Simonidom, piše Bonfini. Razumeo je gotovo sve evropske jezike, sa izuzetkom turskog i grčkog, tvrdi Bonfini. Iz dela Symposion sive de virginitate et pudicitia coniugali, od istog autora, doznaje se da na početku braka sa Beatriče Aragonskom isključivo pričao na latinskom jeziku, jer njegova druga supruga tada nije znala mađarski jezik.

Na njegovo obrazovanje i odgoj presudno je uticao čuveni ugarski i hrvatski humanista, latinista i pisac, varadinski biskup i ostrogonski nadbiskup Ivan Vitez od Sredne (Johannes Vitéz de Zredna). Iz govora kralja Matije, nakon krunisanje, doznaje se da je Vitez po izričitoj želji njegovog oca na samrti, postao učitelj i staratelj budućeg kralja (Bonfinis, 1976, 1). Tokom studiranja u Beču, Bolonji i Padovi, Vitez je upoznao humaniste Enea Silvija Pikolominija (potonjeg papu Pija II), Grgura Sinočkog, Martina Krola, Guarina Mlađeg i druge. Zahvaljujući učitelju, koji je doneo prve humanističke ideje u Ugarsku, za vreme vladavine Matije Korvina dolazi do snažnog procvata humanizma i renesanse. Na njegovom dvoru boravili su vajat Ivan Duknović Trogiranin (Iohannes Dalmata), astronom Regiomontanus, astrolog Marcin Bylica iz Poljske i Peuerbach, minijaturisti Atananti Atavante i Naldo Naldi iz Italije, književnik Galeotto Marzio iz Napulja i mnogi drugi (Kurelac, 1987, 95-107). Kao protonotar tu je boravio i Janoš Turoci (Joannes Thwrocz). On je u Brnu objavio čuveno delo Chronica Hungarorum ab origine gentis. U Matijino vreme započelo je štampanje knjiga u Ugarskoj. Prvi štampar bio je Andreás Hess, koji je početkom sedamdesetih godina XV veka došao iz Nemačke u Budim (Hanák, 1995, 61).

Iz sedme knjige dela Rerum Ungaricarum Decades, tomus IV, doznajemo da je Matija u Recu kod Beča, primio Antonija Bonfinija, rodom iz Askolija Pičena (Bonfinis, 1976, 143). Tom prilikom, italijanski humanista doneo mu je nekolicinu knjiga: prevode Hermogena i Herodijana sa grčkog na latinski, kratku knjižicu o poreklu loze Korvina koju je posvetio kralju, knjigu o supružničkoj smernosti i 
odanosti adresiranu na Beatriče, delo o istoriji Askolija (Historia Asculana), te zbirku epigrama namenjenu Ivanišu, Matijinom sinu. Sa oduševljenjem i entuzijazmom, ugarski vladar pročitao je narečena dela. Uskoro je naredio da Bonfini održi svečani govor dvorjanima u Beču i podeli im svoje knjige. Nakon toga, uposlio je pisca da piše i ujedno čita kraljici različita literarna dela kako se ona ne bi sasvim otuđila od književnosti i filozofije. Inače, Matijina supruga odlično je poznavala dela antičkih pisaca, naročito Vergilija i Cicerona. Koliko je kralj voleo knjige najbolje svedoči činjenica da je osnovao čuvenu biblioteku Korvina (Corvina) koja je brojala oko 2500 naslova. U njoj se nalazilo mnoštvo luksuzno opremljenih knjiga na grčkom i latinskom.

Vredna svake pohvale je i Matijina građevinska delatnost. Obnovio je budimsku tvrđavu i podigao niz veličanstvenih rezidencija. Palate su bile svečano opremljene sa brižljivo izrađenim mozaicima. Toj monumentalnoj delatnosti Bonfini je posvetio poseban epigram i naširoko piše o njoj u svom delu (Bonfinis, 1976, $136,137,138)$. Građevine po luksuzu nisu zaostajale za antičkim uzorima. Okolo su se nalazili prekrasni vrtovi sa lavirintom od grmlja i drveća i ptičnjakom. Restaurirao je i crkvu posvećenu Bogorodici u Stonom Beogradu. Obnovio je i staru kraljevsku tvrđavu u Višegradu. U Tati se, prema Bonfinijevom mišljenju, nalazila najlepša tvrđava u Ugarskoj. Nabrajanje svih njegovih graditeljskih poduhvata i podviga moglo bi biti tema posebnog naučnog rada.

Italijan iz Askolija u svom obimnom delu prikazao je ugarskog kralja kao potomska stare rimske patricijske porodice Valerija, u čijem se grbu nalazio gavran. Od latinskog naziva ove ptice, corvus, nastalo je vladarevo humanističko ime Matija Korvin (Rokai i dr., 2002, 169).

Sa druge strane, mnogi slojevi zamerali su Matiji olako trošenje novca i usvajanje manira iz Italije i Nemačke. U kritikama su naročito oštri bili franjevci (Hanák, 1995, 61). Sa druge strane, kralj je očevidno stremio edukaciji naroda i dodatnom školovanju plemića, naročito u političkim naukama. Želeo je da se u tom pogledu svi povedu za njegovim primerom,.

Bonfini u osmoj knjizi detaljno opisuje i fizički izgled kralja Matije. Bio je "stasa nešto krupnijeg od prosečnog" i izuzetno lepo građen (Bonfinis, 1976, 166). Imao je široka ramena i snažan torzo. Njegove crte lice bile su plemenite, a oči živahne i tamne. Ten mu je bio beo i rumen a kosa plava. Imao je prijatan telesni miris, te ga italijanski pisac poredi sa Aleksandrom Velikim. Prema Plutarhu, koža Aleksandra Makedonskog prijatno je isparavala, usta i celo telo su mu lepo mirisali, "tako da mu je i odelo bilo puno mirisa" (Plutarh, 1987, 104). Italijanski humanista iz Askolija, ujedno i vrstan poznavalac antičke književnosti, na ovom mestu pravi paralelu između Matije i makedonskog vladara koji mu je očigledno poslužio kao uzor.

Poput drugi ljudi, Matija je imao i određene slabosti. Znao je često, piše Bonfini, da uživa u pijanstvu, a ponekad i da podlegne čarima žena neznatnog porekla.

Poredeći Matiju i rimsko-nemačkog cara Fridriha III, u četvrtoj knjizi Bonfini donosi puno podataka o osobinama dva vladara i različitosti nemačke i ugarske 
kulture. Dok je Matija voleo da se opusti uz vino i preda užicima, Fridrih III bio je krut, trezven, nikad nije okusio alkohol i prezirao je pijanstvo. Za razliku od Matije koji je uživao u šalama, smehu i društvu prijatelja, rimsko-nemački car živeo je asketski povučeno, strogo, ozbiljno i bez društva. Dok je Matija olako rasipao novac (mada ga je, kaže Bonfini, podjednako brzo i vraćao u blagajnu), Fridrih III više je mario za novac no za ljude. Ugarski kralj bio je prijatne naravi, veseo i više je držao do časti nego do bogatstva, za razliku od svog suparnika koji je bio tvrdoglav, pohlepan, znatno željniji novca no slave.

Matija je bio veoma temperamentan i sklon da brzo plane. Jedna od njegovih mana bila je izvesna nestalnost u ljubavi prema prijateljima koje je neretko znao prestrogo da kazni. Tu verovatno pisac aludira na Matijin postupak prema Ivanu Vitezu od Sredne. Naime, 1471. izbila je u Ugarskoj zavera protiv kralja. Prema pisanju Bonfinija, Vitez je poslednji pristupio zaveri i za taj postupak optužuje Ivana Česmičkog (Bonfinis, 1976, 48). Sa druge strane navodi da je ostrogonskog nadbiskupa na zaveru navela duboka uvređenost zbog činjenice da se kralj u poslednje vreme uzoholio i oslio, te da nije slušao savete velikaša i saradnika već je sasvim ignorisao njihovo mišljenje. Pišući o pomenutim događajima, italijanski humanista u više navrata ističe da je Vitez bio Matijin "poočim", "roditelj", "plemeniti otac" i "staratelj". Matija je odlučio da kazni prestupnike, gorko svestan da bi preterana popustljivost mogla biti protumačena kao slabost i koštati ga vlasti. Najpre se obračunao sa svojim velikim prijateljem, savetnikom i drugom, Ivanom Vitezom osudivši ga na kućni pritvor. U višegradskoj tvrđavi Vitez je proveo nekoliko meseci. Matiju je bolela činjenica da ga je izdao stari očev prijatelj koji "mu je vazda bio poput roditelja". Na kraju je kralja ipak savladala urođena milostivost. Uz opasku da se kralj bojao ružne slike o sebi, Bonfini pripoveda da je ponovo ustoličio Viteza za nadbiskupa, ne ukinuvši mu, doduše, konstantan nadzor. Vitez je vapio za skorim krajem "držeći da će mu smrt doneti konačno oslobađanje od svih muka i stida" (Bonfinis, 1976, 47). Ivanova smrt izazvala je opštu žalost, a Bonfini ponovo naglašava da je na starca presudno nepovoljno uticao sestrić, Ivan Česmički.

$\mathrm{Na}$ više mesta u delu Bonfini se osvrće na smrt Matijinog ujaka Mihaila Silađija. Pošto izvesno vreme nisu bili u dobrim odnosima, Matija se tokom septembra 1459. godine izmirio sa Silađijem. Poverio mu je odbranu južne Ugarske i vratio ga je na položaj zapovednika Beograda (Thallóczy \& Áldásy, 1907, 248). Međutim, njegov ujak bio je nešto kasnije zarobljen i osuđen na smrt dekapitacijom, u Carigradu 1461. godine (Babinger, 1968, 171; Klaić, 1973, 34). Italijanski humanista ističe da je Matija teško podneo ujakovu smrt smatrajući je velikim gubitkom za čitavo kraljevstvo, dodajući da su pokojnog Silađija dostojno oplakivali svi društveni slojevi u Ugarskoj.

Za srednji vek bila je karakteristična pobožnost, ali i verovanje u zvezde i astrologiju. Smatralo se da zvezde utiču na sudbinu ljudi i događaje na Zemlji. Prema opšteslovenskim predstavama, ako je čovekova zvezda jaka, onda će on lako izaći na kraj sa svim svojim nevoljama. Na početku treće knjige, Bonfini 
piše o zvezdi pod kojom je rođen Matija. Iako je neprekidno bio izložen opasnostima, uvek je uspevao da ostane na vrhuncu svojih sposobnosti. Hrabar poput Herakla, podjednako dobro nosio se kako sa unutrašnjim, tako i sa spoljnim potresima.

Za Matiju, Bonfini kaže da je u životu je generalno imo sreće. Kao primer navodi događaj prilkom rata protiv Čeha, kada je u potpunosti ostao bez novca za isplatu saboraca. Ako je verovati piscu, kralj se jedne noći kockao, dobijao je sve moguće kombinacije i na kraju zaradio oko 10000 dukata kojima je potom isplatio vojnike.

Savremenici su intezivno pomračenje Sunca, 18. marta 1484. godine, kada su se usred bela dana na nebu mogle videti zvezde, protumačili kao najavu pada Beča u skorijoj budućnosti. Kralj Matija je čitava tri dana čekao najpovoljniji položaj zvezda kako bi, nakon zauzeća grada, trijumfalno ujahao u Bečko Novo Mesto.

Pre svake vojne kampanje obavezno je konsultovao astrologe, te se po njihovom savetu držao opreznije ili odvažnije. Primera radi, pre nego što je 1477. započeo rat protiv Fridriha III, konsultovao je predviđanje astrologa (Bonfinis, 1976, 80). Oslanjao se na zakonske spise, mišljenje senatora i astrologa. Istovremeno, organizovao je verske službe u svim crkvama kako bi zadobio Božiju naklonost. Bonfini piše u petoj knjizi da je Matija u Ugarsku doveo stručnjake iz raznih zemalja i iz svih mogućih oblasti (astronome, lekare, matematičare, pravne savetnike) a "nije prezao ni od magova, gatara $i$ astrologa jer je prema svakoj veštini gajio dužno poštovanje". Vladar je tokom 1489. bio upozoren od strane astologa da će tokom septembra i novembra doći do pogoršanja njegovog zdravstvenog stanja. Ispostavilo se da su bili u pravu jer je u narečenom periodu imao težak napad groznice. Tek nakon njenog smirivanja, posle Božića, krenuo je put Beča. Matija i Fridih III bili su jednako pobožni, ali nisu krili "sklonost prema gatarima i astrolozima”, saznaje se iz četvrte knjige dela Rerum Ungaricarum Decades, tomus IV. I Fridrihov sin Maksimilijan imao je ličnog astrologa koji ga je obavestio da će Matija umreti 1490. godine. Stoga je neprestano slao legate kralju kako bi se obavestio o stepenu pogoršanja njegovog zdravlja.

Matijina druga supruga bila je Beatriče, kći napuljskog kralja Feranta (Ferdinanda) Aragonskog (1458-1494). Kralj Matija Korvin se opsežno i veoma detaljno pripremao za venčanje. Izdvojio je za tu prigodu, piše Bonfini, "ludačke sume novca". Luksuz i raskoš prevazilazili su blještavilo drevnih Persijanaca. Najpre je uputio glasnika, prvaka većnice Stonog Beograda, Fridrihu III i ostalim nemačkim velikašima, te ih je zvanično pozvao na svečanost. I druge ugledne vladare pozvao je da prisustvuju ceremoniji venčanja, kao i sve ugarske plemiće. U Napulj je uputio desetoricu velikaša koji su bili sjajno opremljeni, otmeni i uglađeni. Na čelu delegacije nalazio se velikovaradinski biskup Ivan, jedan od najbližih Matijinih saradnika, čovek izuzetno obarzovan i mudar. Pisac ne beleži poimence ostale članove delegacije. Među njima, između ostalih, nalazili su se Petar Gereb, Ivan Pongrac, grof Ivan od Sv. Jurja i Bozina, knez Bernardin Frankopan (Klaić, 
1973, 124). Na putu, zaustavljajući se u usputnim gradovima, trudili su se da sve zasene sjajem i luksuzom svoje trpeze. Sve je sijalo od zlata, srebra i dragulja. Urbanskog vojvodu posebno je impresionirala posuda za so od žeženog zlata, načičkana dragim kamenjem, kao i zlatni ibrik optočen draguljima i sedefom. Dakle, vodilo se računa i o najsitnijim detaljima kako bi se prikazali bogatstvo i sjaj srednjovekovne Ugarske.

U Sipontu se delegacija na čelu sa kraljicom ukrcala na tri velike lađe. Beatriče je u svojstvu tutora pratio vojvoda Adrijan. Delegacija je sjajno primljena u Ferari, gde je živela njena sestra Eleonora. Veliku gostoljubivost pokazala je i Venecija. Zahvaljujući mletačkim poslanicima na čestitkama, Beatriče je održala sjajan govor. Kraljica je potom preko Furlanije, Istre i Kranjske doputovala u Ugarsku (Berzeviczy, 1914, 20-33).

Jedino je iščekivanje kraljičinog dolaska ublažavalo Matijin vojnički entuzijazam i osujetilo njegove ratne planove. Tada je prvi i poslednji put u životu privatni život stavio na prvo mesto u odnosu na državne poslove i vojne obaveze. Za ćerku napuljskog kralja govorilo se da je bila izuzetno lepa, otmena, čedna, rečita i vična retorskoj veštini. Bonfini beleži da je Matija bio "već prilično zaljubljen u samu predstavu o njoj", pre nego što ju je prvi put video. U nastavku teksta, italijanski pisac dodaje da, ukoliko neko želi "da dozna kakva je kraljica uistinu bila", neka pročita njegovo delo $O$ ženskoj čednosti.

Kraljevu zaokupljenost venčanjem iskoristili su Turci koji su napali Dalmaciju i pričinili veliku štetu. Sa druge strane, pripreme za skorašnje venčanje odvraćale su Matiju od planiranog pohoda na Smederevo. Kraljičina pratnja imala je priliku da vidi tragove turskog pustošenja po Dalmaciji, što je izazvalo opštu žalost. Tek pošto su prešli reku Dravu, osetili su olakšanje. Dodatni problem za putnike predstavljali su hladna zima i visoki nanosi snega. Matija je konačno 10. decembra sačekao Betriče u Stonom Beogradu. Kraljica je ujahala u grad preko crvenog tepiha, čija je dužina iznosila $1,5 \mathrm{~km}$. Primljena je uz veliku pompu i ovacije. Njena pojava opčinila je Matiju na prvi pogled. Prema Bonfiniju, ona je "lepotom podsećala na Veneru, čednošću na Dijanu, a mudrošću i rečitošću na Paladu Atenu" (Bonfinis, 1976, 69). Tu je obavljeno njeno svečano krunisanje. Nakon toga, 13. decembra 1476. godine krenuli su za Budim gde je upriličena ceremonija venčanja. Sama proslava trajala je danima, uz svečane gozbe i raznorazne prateće manifestacije. Novopečeni mladenci primili su brojne darove koji su, prema Bonfiniju, "do vrha napunili kraljevsku riznicu". Uz to, zbog slavlja su na slobodu pušteni svi zatočenici, odloženi sudski procesi i vraćanje dugova. Matija je bio do te mere opčinjen kraljičinom lepotom da nije bio u stanju bez nje da provede ni sat vremena.

Osmanlije su maksimalno iskoristili Matijinu zaokupljenost venčanjem. Ugri su tokom 1476. podigli "tri kaštela od drveta i nabijene zemlje" u okolini Smedereva. Dok je čitava Ugarska bila zaokupljena Matijinom svadbom, Turci su sakupili 40000 ljudi. Iskoristvši zaleđenu reku i zauzetost stanovnika Vlaške i Transilvanije kraljevim venčanjem, sa 30000 konjanika obrušili su se na ove teritorije. Pustošili su "ognjem i mačem" sve pred sobom, zarobivši čak 40000 ljudi, a potom 
se povukli u Meziju. Dakle, u zimu 1476. stradale su Dalmacija, Mezija i Dakija. Svi događaji "prilično su potresli Matiju i sasvim usmerili njegove misli na nastavak rata protiv Turaka". Uskoro su porušeni i kašteli kod Smedereva (Novaković, 1886, 15-16; Fraknói, 1893, 359; Stojanović, 1929, 250-251; Babinger, 1968, 301).

Kraljica ga je često pratila prilikom vojnih pohoda. Čitavih deset godina nije se odvajao od nje ni koraka "do te mere da su ga mnogi smatrali papučarom". Nešto kasnije u tekstu Bonfini konstatuje da je Matija nakon Beatričinog dolaska postao povučeniji i malo manje pristupačan (Bonfinis, 1976, 134). Pošto u braku nisu imali dece, Matija je nastojao da presto osigura vanbračnom sinu Ivanišu, neumorno radeći na njegovom obrazovanju i usavršavanju (Bonfinis, 1976, 139). Iako iskreno posvećen tome, Matija se nije usudio da preduzme konkretnije korake $u$ narečenom smeru jer se tome žestoko protivila Beatriče. Premda o tome Bonfini ne piše, mnogi savremenici zamerali su Matiji favorizovanje rodbine njegove suprige. On je na položaj ostrogonskog nadbiskupa prvo postavio Jovana Aragonskog, Beatričinog brata, a potom sestrića Ipolita Estea (Rokai i dr., 2002, 170). Šroki slojevi stanovništa nisu blagonaklono gledali ni na preterano trošenje novca za kraljevsko venčanje.

Rezimirajući Matijin život, Bonfini ističe da je on u suštini bio veoma skroman čovek. Uživao je u jednostavnom, svakodnevnom životu. Nosio je običnu odeću i samo u adekvatnim prilikama pokazivao sjaj i bogatstvo. Za razliku od većine evropskih vladara, Matija nije bio čovek koji insistira na raskoši purpurne i zlatne vladarske odežde. Nije bio okružen gomilom posluge, vratara ili posrednika. Ugarski kralj bio je duhovit čovek i ljubitelj dobre šale. Umeo je "neretko da bude neposredan i sa prijateljima opušteno večera u kuhinji”.

Brojna znamenja su, piše Bonfini, nepogrešivo najavila smrt najvećeg vladara srednjovekovne Ugarske. Neverovatnu oluju 1. januara 1490. godine u Beču svi su "doživeli kao loš predznak" i "ozbiljno se zabrinuli za kraljevo zdravlje" (Bonfinis, 1976, 162). Nakon njegove smrti, Dunav je toliko nadošao da je "poplava uništila brojna obližnja sela i gradove". Ona kao da je predskazivala stradanje Ugarske od najezde Turaka. Na dan Matijine smrti "uginuli su svi lavovi koji su bili čuvani u Budimu" a nije se mogao videti ni jedan jedini gavran "znameniti simbol loze Korvina". Sve to su nepogrešivo predvideli gatari, proroci i astrolozi. Ovi poslednji upozorili su i Fridrihovog sina Maksimilijana da će se te godine Matija upokojiti. Tokom februara i marta 1490. godine "sa dolaskom kiše i vlažnog vremena" njegovo zdravstveno stanje se pogoršalo. O njegovom zdravlju brinuli su Đulio Emilio i još jedan lekar iz Italije. Pošto je malo ojačao, kralj se posvetio pripremama za proslavu Uskrsa (Fraknói, 1896, 317). Posle čitavih šest sati ceremonije, na Cvetnu nedelju 1490. godine, doživeo je moždani udar. Pred smrt je zatražio da mu donesu smokava iz Pičena. Neki autori skloni su mišljenju da su smokve bile otrovane i da je to prouzrokovalo kraljevu smrt (Sremac, 1987, 18). Njegova poslednja borba trajala je nepuna tri dana. Kralj je sklopio oči u utorak, 6. aprila 1490. godine, između 7 i 8 sati ujutru. Prema odluci Senata organizovana su dva sprovoda, jedan u Beču, a drugi u Stonom Beogradu (Bonfinis, 1976, 164). O Matiji kao "pravednom kralju" 
dugo se govorilo nakon njegove smrti (Hanák, 1995, 52). Prema Bonfiniju, "sa Matijom kao da su nestali slavno ime i ponos Ugarske" (Bonfinis, 1976, 169).

Italijanski humanista donosi jedanu veoma interesantanu epizodu kojoj je lično prisustvovao. Naime, kada je 1489. godine kralj sa pratnjom putovao iz Beča za Budim, u Komaromu je na vrhu kapije ugledao rodino gnezdo. Svi su zastali pred prizorom četiri rode koje su oterale petu i žestoko se otimale oko njenog negdašnjeg gnezda. Sam kralj konstataovao je tada da će uskoro umreti i da će se Ugarska podeliti na nekoliko frakcija, tj. da će se četiri kralja otimati o presto (Bonfinis, 1976, 162). Nakon njegove smrti, u dramatičnim trenucima za krunu sv. Stefana uistinu su se i otimale četiri frakcije, odnosno, kako Bonfini piše - računajući kao petu snage mladog Ivaniša Korvina - "pet različitih struja i svaka je jednako vukla na svoju stranu" (Bonfinis, 1976, 171). Bili su to, dakle, rimsko-nemački car Fridrih III Habzburški i njegov sin Maksimilijan (nemački kralj 1493-1508 i rimsko-nemački car 1508-1519), potom sinovi poljskog kralja Kazimira IV, češki kralj Vladislav i njegov brat Jan Olbraht, te loza Aragona, a najzad i maločas pomenuti Matijin vanbračni sin, Ivaniš Korvin.

\section{IZVORI I LITERATURA}

Babinger, F. (1968). Mehmed Osvajač i njegovo doba. Novi Sad: Matica srpska.

Berzeviczy, A. (1914). Aragoniai Beatrix magyar kiralyné életére vonatkozó okiratok. Budapest: Kiadja a Magyar tud Akadémia.

Božanić, Snežana (2012). O ratu između Matije Korvina i Đorđa Pođebrada u svetlosti kazivanja Bonfinija. Годишњак ФФ у Новом Саду, XXXVII-1, 415-425. Preuzeto sa http:// www.epub.digitalnabiblioteka.tk/index.php/gff/article/view/209.

Božanić, S, \& Kisić, M. (2013). Rerum Ungaricarum Decades, decas IV, kao izvor za proučavanje istorije srednjovekovne Ugarske u periodu od 1464. do 1465. godine. U: Hardi, Đ. (ured.) (2013). Srednjovekovna naselja na tlu Vojvodine. Istorijski procesi i događaji (str. 159-172). Sremska Mitrovica: Filozofski fakultet, Odsek za istoriju.

Bonfinis, A. (1976). Rerum Ungaricarum Decades, tomus IV - pars II. Budapest: Akademiai Kiado.

Dinić-Knežević, Dušanka (1975). Sremski Brankovići. Istraživanja, 4, 5-47.

Ivić, A. (1909). Iz istorije Srba u Ugarskoj, od pada Smedereva so smrti despota Vuka (14591485). LMS, 260, sv. VIII, 20-43.

Ivić, A. (1929). Istorija Srba u Vojvodini od najstarijih vremena do osnivanja Potisko-Pomoriške granice (1703). Novi Sad: Matica srpska.

Jorga, N. (1934). Istorija Rumuna i njihove civilizacije. Vršac: Jugoslovenska štamparija M. P. Stefanović.

Kisić, M. (2012). Ustanak u Moldaviji 1467. godine kroz pero Antonija Bonfinija. U: Gavrilović, V. (ured). (2012). Vojvođanski prostor u kontekstu evropske istorije (str. 27-38). Novi Sad: Filozofski fakultet, Odsek za istoriju.

Klaić, V. (1973). Povijest Hrvata, od najstarijih vremena do svršetka XIX stoleća, knjiga četvrta. Zagreb: Nakladni zavod MH.

Kurelac, M. (1987). Hrvatski humanisti rane renesanse. Croatica Christiana periodica, 19, 95-107. 
Novaković, S. (1886). Poslednji Brankovići, u istoriji i narodnom pevanju, 1456-1502, II. LMS, 147, 1-32.

Plutarh (1990). Slavni likovi antike II. Novi Sad: Matica srpska.

Radonić, J. (1911). Grof Đorđe Branković i njegovo vreme. Beograd: SKA.

Radonić, J. (1923). Prilozi za istoriju braće Jakšića. Spomenik SKA, 59, 61-76.

Rokai, P., Đere, Z., Pal, T., \& Kasaš, A. (2002). Istorija Mađara. Beograd: Clio.

Ruvarac, I (1934). Prilošci, v) Feyezkö=Slankamen? U: Radojčić, N. (ured.) (1934). Zbornik Ilariona Ruvarca: odabrani istoriski radovi I, Politička istorija, istorija književnosti, istoriska geografija i kritika (str. 299-302). Beograd: SKA

Sremac, Đ. (1987). Poslanica o propasti ugarskog kraljevstva. Beograd:

Stojanović, Lj. (1927). Strai srpski rodoslovi i letopisi. Beograd-Sr. Karlovci: SKA.

Thallóczy, L., \& Áldásy, A. (1907). Magyarország melléktartományainak oklevéltára II, A. Magyarország és Szerbia közti összeköttetések oklevéltára, Monumenta Hungariae historica, Diplomataria XXXIII. Budapest: Kiadja a Magyar tudományos Akadémia.

Ćirković, S. (1970). O despotu Vuku Grgureviću. Zbornik Matice srpske za likovne umetnosti, 6, 283-290.

Fraknói, V. (1896). A Hunyadiak és a Jagellók kora (1440-1526). Budapest: Kiadja az athenaeum irodalmi és nyomdai részvénytársulat.

Fraknói, V. (1893). Mátyás király levelei I. Budapest: Magyar Tudományos Akadémia.

Hanák, P. (1995). Povijest Mađarske. Zagreb: Barbat.

Huszti, J. (1927). Janus Pannonius asztrologiai álláspontja. Minerva, 5, 43-58.

Snežana M. Božanić, Milica D. Kisić Božić

\section{OBVERSE AND REVERSE OF A KING: THE PORTRAIT OF MATTHIAS CORVINUS IN THE HISTORIOGRAPHICAL WORK OF AN ITALIAN HUMANIST}

\section{SUMMARY}

The paper examines the portrait of king Matthias Corvinus from the point of view of an Italian humanist Antonio Bonfini. The first eight books of the fourth decade of his work Rerum Ungaricarum decades are dedicated to the aforementioned Hungarian ruler. Chronologically, the paper covers the period from Matthias' coronation in 1464 until his death in 1490. Bonfini's testimony is compared to other relevant historical sources dealing with the same topic. Many scholars have, on numerous occasions, underlined Bonfini's alleged lack of objectivity in portraying the Hungarian king. However a detailed scrutiny of his work suggests different conclusions: the truth is that the author, while undoubtedly praising Matthias' virtues, at the same time doesn't hesitate to portray his weaknesses and vices as well. The king was indeed a great warrior, successful in numerous war campaigns. The examples of his heroic acts mentioned in Bonfini's work are easy to prove by comparing the author's claims to other historical sources. According to Rerum Ungaricarum decades, the king was very open-minded and generous, always striving for honor and glory. Versatilly educated, he supported the cultural movement of Humanism \& Renaissance in Hungary. Although a very pious Christian, Matthias was also superstitious to the extent that he never started a war campaign before consulting astrologists and soothsayers. The king was rather generous and gallant towards his military commanders and friends. Despot Vuk Grgurević, the Jakšić brothers, Pavle Kinjiži, Stefan Batori were all granted with possessions for their war merits. 
On the other hand, the king was rather cruel to his enemies. In 1465, he took a horrible vengeance on Švehla and the Czech Brotherhood. He also showed little mercy to his tutor and close friend, archbishop Ivan of Sredna, after the old man betrayed him in 1471. Matthias' army is remembered to be pretty ferocious on many occasions, especially during the campaign against Austria in 1477. The king loved his wife Beatrice of Aragon very much, but her arrival brought many radical changes to his lifestyle and made him less accessible to ordinary people. Although he aspired to leave the crown to his illegitimate son Ivaniš Korvin, the king didn’t dare to carry out this idea due to his wife's objections. According to Bonfini, "when Matthias died, the pride \& glory of Hungary were forever lost". The events that followed justify his claim. 